\title{
DETERMINATION OF OPTIMUM VALUE OF STABILISER FOR STABILISATION OF BLACK COTTON SOIL USING CEMENT, GGBFS AND METAKAOLIN
}

\author{
Uma.G.Hullur \\ Assistant professor Department of Civil Engineering, \\ K.L.S. Gogte Institute of Technology Belagavi, Karnataka, India. \\ Dr.S. Krishnaiah \\ Professor Department of Civil Engineering, \\ Jawaharlal Nehru Technological University, Anantapur, Andra Pradesh, India. \\ Dr.K.B.Prakash \\ Principal, Government Engineering College Haveri, \\ Karnataka, India.
}

\begin{abstract}
India is a country of different types of soil, of which the black cotton soils (BC soil) are one of the major soil deposits. BC soils are seldom used to support buildings or pavements because of its complicated behaviour. Generally, $\mathrm{BC}$ soils have a very low bearing capacity and high swelling and shrinkage characteristics when it is saturated and because of its higher degree of compressibility resulting in settlements, and subsequently leading to failure. But due to the lack of space for the growing population of our country make it necessary to build structures supported on BC soil. Hence in order to overcome this problem the alternate method to improve properties and characteristics of the $\mathrm{BC}$ soil practically was by stabilisation.
\end{abstract}

The main objective of soil stabilisation is to improve the performance of soil by increasing its strength, Stabilisation of BC soil by using industrial waste and convention stabiliser such as cement proved to be a sustainable option. This paper present the test results on study of BC soil stabilised by using Cement, GGBFS and Metakaolin and later which were together blended with $\mathrm{BC}$ soil to determine its influence on stabilisation over cohesive property of stabilised BC soil.

The BC soil was sampled from Belagavi region of Karnataka district and was mixed with Cement, GGBFS and Metakaolin with Varying percentage i.e. $0 \%$ to $10 \%$, $20 \%$ and $30 \%$ by dry weight of soil respectively. The aim of the investigation was to find the effects of stabilizers on various geotechnical properties of the BC soil. From experimental studies it was found that the maximum dry density was achieved at $30 \%$ for all the stabilisers. The cohesion of the stabilised soil was also maximum at $30 \%$.Further, when the BC soil was treated with ternary blend( $\mathrm{BC}$ soil+C+GGBFS+MK) with varying percentage of $10 \%, 20 \%$ and $30 \%$ by dry weight of $\mathrm{BC}$ soil, A significant improvement of cohesive property of stabilised soil was observed at $30 \%$ of ternary blend i.e. (70\% BC soil+30\% (C+GGBFS+MK)). This study proved a significant enhancement in the engineering performance of waste-stabilised ternary blended BC soil which can be employed in the structural applications such as highway construction work and also in the stabilisation of existing BC soil for foundations.

Keywords: Black cotton soil, soil stabilisation, Cement, GGBFS, Metakaolin

\section{INTRODUCTION}

The materials of the earth crust is divided into two, soil and rock in civil engineering. Soil is a natural mineral grains of the rock mass. It is a material supporting the vegetation depending upon their origin soil can be classified into different types, In general as sand, silt, clay, peat etc. Clay is an aggregate of microscopic and sub microscopic particle derived from chemical composition of rock. It is also a most complicated soil because when it comes in contact with water it swells and it shrinks when pore water expels out. Hence this behaviour makes the clay soil as the most complicated soil. All the clay minerals are crystalline hydrous which have lattice structure in which the atoms are arranged in several layers, this determines the type of clay mineral. The different important types of clay mineral are, Kaolinite, Illite and Montmorillonite. Karl Terzagi states, the presence of Montmorillonite mineral is the cause of high plasticity index and high frictional resistance

Civil Engineers are interested in construction projects; As a result it is always not possible to have a good foundation soil for constructions. It may be some 
time inevitable to use the site consisting of clayey soil for construction. Therefore to utilise the site of low strength or the soil for pavement construction, it can be stabilised by using some chemicals or industrial wastes or byproducts so that it can satisfy the civil engineering requirements. Many authors suggest different materials, methods to stabilise the clayey soil.

\section{MATERIALS AND METHODOLOGY:}

In most of the papers, Chen, F.H. (1988), Erdal Cocas.et.al (2009), Ismaiel H.A.H. (2006) highlighted that through stabilisation process it is possible to improve the engineering properties of the soil either in the field or in construction where soil is used as construction material. In the present study the Black cotton soil was collected from Belagavi region of Karnataka state, and the initial tests on the black cotton soil was conducted to understand the geotechnical properties of the soil and studied for the improvement over stabilization by using ternary blends, the materials used for stabilising the BC soil are Cement (C), Ground Granulated Blast Furnace Slag (GGBFS) and Metakaolin (MK). The chemical composition obtained by X-ray fluorescence $(\mathrm{XRF})$ of the stabilisers used in this study are,

Table: 1 Chemical composition of stabilisers

\begin{tabular}{|l|l|l|l|}
\hline Property & Cement & $\begin{array}{l}\text { Ground granulated } \\
\text { blast furnace slag }\end{array}$ & Metakaolin \\
\hline $\mathrm{SiO}_{2}$ & $21.9 \%$ & $33.80 \%$ & $54.3 \%$ \\
\hline $\mathrm{Al}_{2} \mathrm{O}_{3}$ & $6.9 \%$ & $13.68 \%$ & $38.3 \%$ \\
\hline $\mathrm{Fe}_{2} \mathrm{O}_{3}$ & $3 \%$ & $0.4 \%$ & $4.28 \%$ \\
\hline $\mathrm{CaO}$ & $63 \%$ & $43.2 \%$ & $0.39 \%$ \\
\hline $\mathrm{MgO}$ & $2.5 \%$ & $0.46 \%$ & $0.08 \%$ \\
\hline $\mathrm{SO}_{3}$ & $1.7 \%$ & - & $0.03 \%$ \\
\hline
\end{tabular}

Table: 2 shows the different test on $\mathrm{BC}$ soil conducted in the laboratory to know the geotechnical properties of BC soil.

Table: 2 Properties of BC soil.

\begin{tabular}{|l|l|l|}
\hline $\begin{array}{l}\text { Sl } \\
\text { No }\end{array}$ & Laboratory Tests & Results \\
\hline 1 & Liquid Limit (\%) & 87.2 \\
\hline 2 & Plastic Limit (\%) & 52.06 \\
\hline 3 & Plasticity Index & 35.14 \\
\hline 4 & Optimum Moisture content(OMC)\% & 23 \\
\hline 5 & Max Dry Density(MDD)KN/M ${ }^{3}$ & 13.826 \\
\hline 6 & Cohesion $(\mathrm{C}), \mathrm{KN} / \mathrm{M}^{2}$ & 29.418 \\
\hline 7 & Angle of internal friction( $\Phi)^{\mathrm{o}}$ & 13 \\
\hline 8 & UCS ,KN/M & 127.478 \\
\hline 9 & CBR Value & \\
\hline & Unsoaked 2.5mm & $6.13 \%$ \\
\hline & \multicolumn{1}{|c|}{$5.0 \mathrm{~mm}$} & $2.18 \%$ \\
\hline & Soaked 2.5mm 5.0mm & $3.65 \%$ \\
\hline & \multicolumn{1}{|c|}{ (Casagrande } & $\mathrm{CH}$ \\
\hline 10 & $\begin{array}{l}\text { Classification of soil (CS) } \\
\text { plasticity chart USCS) }\end{array}$ \\
\hline
\end{tabular}

Knowing the behaviour of the soil, Different stabilisers were mixed with different percentage by dry weight of soil such as $10 \%, 20 \%$ and $30 \%$ and the test were conducted for the different mix proportions. Laboratory test results for soil blended with
individual stabiliser

Table: 3

\begin{tabular}{|l|l|l|l|}
\hline Test & $\begin{array}{l}\text { BCS+ } \\
\text { GGBFS } \\
10 \%\end{array}$ & $\begin{array}{l}\text { BCS+ } \\
\text { GGBFS } \\
20 \%\end{array}$ & $\begin{array}{l}\text { BCS+ } \\
\text { GGBFS } \\
30 \%\end{array}$ \\
\hline $\begin{array}{l}\text { Blended } \\
\text { Specific } \\
\text { gravity }\end{array}$ & 2.34 & 2.35 & 2.43 \\
\hline $\begin{array}{l}\text { Liquid } \\
\text { limit\% }\end{array}$ & 62 & 53 & 46.5 \\
\hline $\begin{array}{l}\text { Plastic } \\
\text { limit\% }\end{array}$ & 49.44 & 41.73 & 37.22 \\
\hline $\begin{array}{l}\text { Plasticity } \\
\text { index }\end{array}$ & 12.56 & 11.27 & 9.28 \\
\hline
\end{tabular}

From the test results it is observed that with the increase in the percentage of the cement content, the blended specific gravity of cement and soil is decreased. The liquid limit of $\mathrm{BC}$ soil which was about $87.2 \%$ was reduced on addition of stabiliser, thus increasing the plastic limit and reducing the plasticity index.

Table: 4

\begin{tabular}{|l|l|l|l|}
\hline Test & $\begin{array}{l}\text { BCS+C1 } \\
0 \%\end{array}$ & $\begin{array}{l}\text { BCS+C } \\
20 \%\end{array}$ & $\begin{array}{l}\text { BCS+C } \\
30 \%\end{array}$ \\
\hline $\begin{array}{l}\text { Blended } \\
\text { Specific } \\
\text { gravity }\end{array}$ & 2.82 & 2.79 & 2.5 \\
\hline $\begin{array}{l}\text { Liquid } \\
\text { limit\% }\end{array}$ & 67.7 & 73.62 & 78.5 \\
\hline $\begin{array}{l}\text { Plastic } \\
\text { limit\% }\end{array}$ & 41.07 & 57.93 & 64.65 \\
\hline $\begin{array}{l}\text { Plasticity } \\
\text { index }\end{array}$ & 26.63 & 15.69 & 13.85 \\
\hline
\end{tabular}

From the table; 4 it is observed that with the increase in the percentage of the GGBFS content, the blended specific gravity of GGBFS and soil is increased. The liquid limit of blended $\mathrm{BC}$ soil was reduced on addition of stabiliser, thus decreasing the plastic limit and reducing the plasticity index. 
Table: 5

\begin{tabular}{|l|l|l|l|}
\hline Test & $\begin{array}{l}\text { BCS+ } \\
\text { MK } \\
10 \%\end{array}$ & $\begin{array}{l}\text { BCS+ } \\
\text { MK } \\
20 \%\end{array}$ & $\begin{array}{l}\text { BCS+ } \\
\text { MK } \\
30 \%\end{array}$ \\
\hline $\begin{array}{l}\text { Blended } \\
\text { Specific gravity }\end{array}$ & 2.43 & 2.54 & 2.65 \\
\hline Liquid limit\% & 68.1 & 67.8 & 63.4 \\
\hline Plastic limit\% & 51.19 & 38.62 & 36.93 \\
\hline Plasticity index & 16.19 & 26.47 & 29.18 \\
& & & \\
\hline
\end{tabular}

From the table: 5 it is observed that with the increase in the percentage of the MK content, the blended specific gravity of MK and soil is increased. The liquid limit of blended BC soil was reduced on addition of stabiliser, thus decreasing the plastic limit and increasing the plasticity index.

Figure: 1

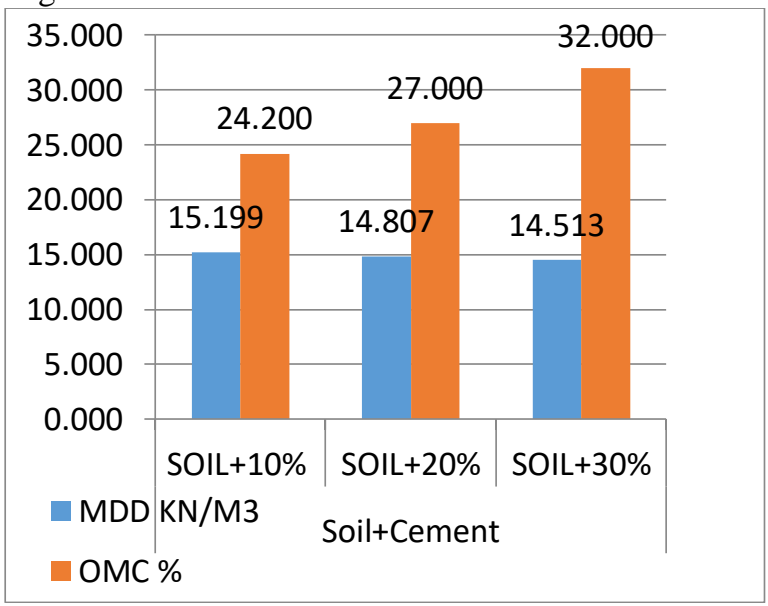

Figure: 1shows the behaviour of the $\mathrm{BC}$ soil when mixed with different percentages of cement. Here with the increase in cement content, there is decrease in the maximum dry density with increase in OMC.

Figure: 2

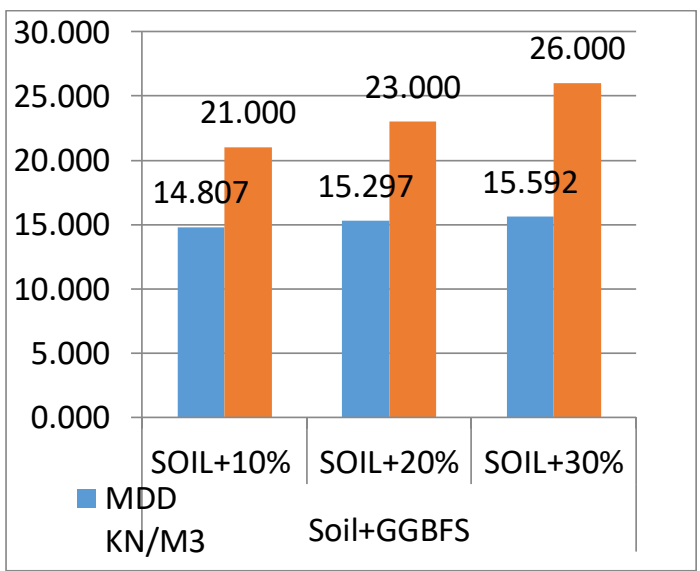

Figure: 2 shows that the maximum dry density of BC soil on addition of GGBFS with varying percentage shows increase in the value of MDD along with increase in the OMC.

Figure: 3

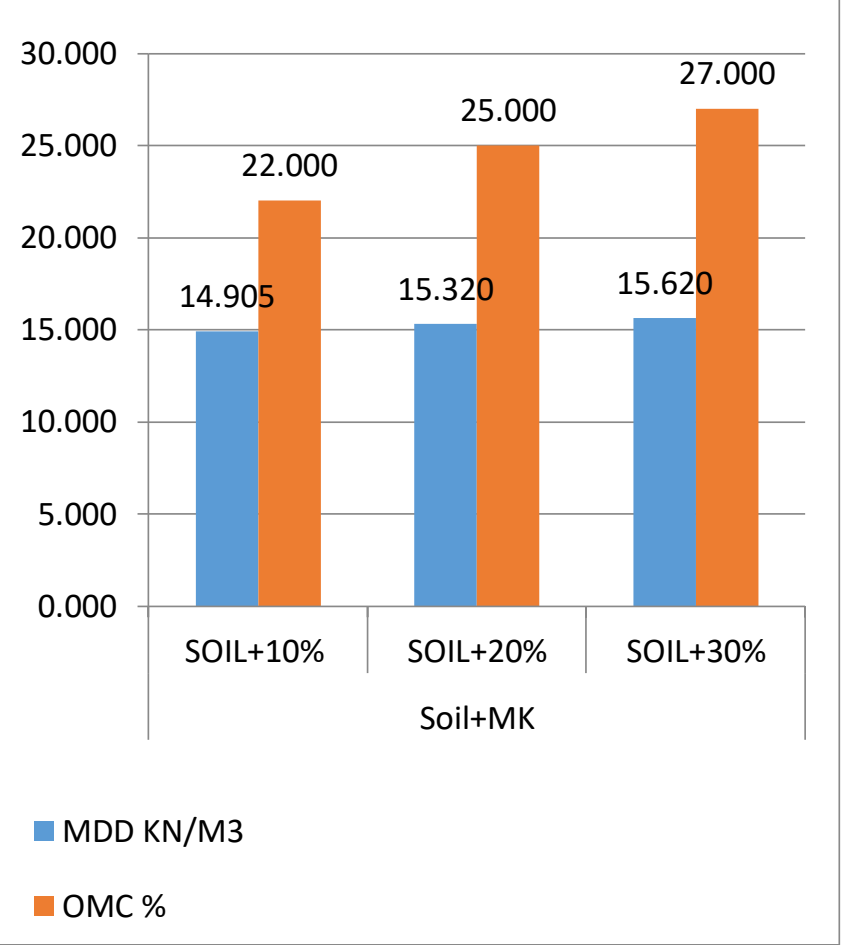

From Figure: 3 it can be understood that the trend remains the same for both MDD and OMC. Therefore maximum density was achieved for $30 \%$ of addition of $\mathrm{MK}$ to $\mathrm{BC}$ soil with increase in OMC.

As per the literature because on addition of more cement to soil the plasticity index reduces with increase in OMC. The soil becomes very hard this cannot be used for construction of pavement or in foundation stabilisation.

\section{CONCLUSIONS}

1. From the test result on the BC soil it was clear that the soil is highly compressive clay whose liquid limit is very high.

2. When the BC soil was blended with Cement, GGBFS and MK with varying percentage such as $10 \%, 20 \%$ and $30 \%$, it showed that for Cement stabilised $\mathrm{BC}$ soil the liquid limit increased with increase in the content of cement. For GGBFS and MK the trend remained the same that is there is decrease in the liquid limit, But when the value are compared with the result of $\mathrm{BC}$ soil alone, it shows decreasing trend.

3. To determine the optimum value of the stabiliser, proctor test was conducted from the 
result it can be concluded that $10 \%$ cement gives maximum MDD but GGBFS and MK showed the maximum MDD at $30 \%$

4. The above results can be applied for stabilizing the $\mathrm{BC}$ soil for structural application and in construction of roads.

\section{REFERENCES}

[1] AASHTO (1986). 'Standard Specifications for Transportation Materials and Methods of Sampling and Testing', American Association for State Highway and Transportation Officials, 14th Ed. Washington, D.C

[2] Mitchell, J.K. (1976), Fundamental Of soil Behaviour. John Wiley and Sons, Inc., New York, 422p

[3] Nelson,D.J. and Miller, J.D.(1992). Expansive Soils: Problems and Practice in Foundation and Pavement Engineering, John Wiley \& Sons, Inc. New York.

[4] Chen, F.H. (1988).Foundation of Expansive soils, Elsevier Scientific Pub.Co. Amsterdam

[5] Erdal Cocas, VeyselYazici, VehbiOzaydin (2009) "Stabilization of Expansive clays using ground granulated blast furnace slag \& cement", Geotechnical\& Geological Engineering Journal, Vol.27, pp 489-499

[6] Jiang L, Chirdchanin M, Katsutada O (2005) "Stabilization effects on surplus soft clay with cement \&ground blast furnace slag", Journal of Environmental Sciences, Vol.16, No.3, pp 397-403

[7] Karl Terzaghi Third Edition. 'Soil Mechanics in Engineering Practice Wiley. India.

[8] Brook-Bradley HE (1952) "Soil-cement roads in Worcestershire", Surveyor 3, pp 571-573.

[9] Ismaiel H.A.H. 2006: Treatment and Improvement of the Geotechnical Properties of Different Soft Fine-grained Soils Using Chemical Stabilization. Shaker, Aachen.

[10] Manjunath S. Sharanappanavar, ShrutiByadgi, PriyaBhosale, SwatiNooli, SnehalHindalkar, Savitri Khot, 2017. "AStudy on Influence of GGBFS, Egg Shell Powder and Solid Waste Incinerated Ash to Improve the Index Properties of Black Cotton Soil" International Journal of Engineering Technology Science and Research IJETSR, ISSN 2394 - 3386 Volume 4, Issue 6.

[11] Anil Kumar Sharma and P.V. Sivapullaiah,'Improvement of Strength of Expansive soil with waste Granulated Blast Furnace Slag", Geo Congress 2012 Oakland, California, United States PP 3920-3928.

[12] Hassnen M. Jafer, William Atherton, Monower Sadique Felicite Ruddock, and Edward Loffil (2018): "Development of a new ternary blended cementitious binder produced from waste materials for use in soft soil stabilisation". Journal of Cleaner Production 172 (2018) 516-528 